\title{
Change in the stability of goat milk and cow milk due to $\mathrm{pH}$ and heat
}

\author{
Xiaoxue Fan ${ }^{1}$, Ming Cheng ${ }^{2}$, Xiaoning Zhang ${ }^{1}$, Cunfang Wang ${ }^{1 *}$, Hua Jiang ${ }^{1 *}$ \\ ${ }^{1}$ College of Food Science and Engineering, Qilu University of Technology (Shandong Academy of Sciences), Jinan, China \\ ${ }^{2}$ Qingdao Institute of Animal Husbandry and Veterinary Medicine, Qingdao, China
}

\begin{abstract}
This paper aimed to evaluate the changes in the thermal stability of goat milk, cow milk and homogenized milk under different $\mathrm{pH}$ conditions. The results showed that goat milk was of type B milk, and the thermal stability were positively correlated with the $\mathrm{pH}$ value. But cow milk was of type A milk, the most stable $\mathrm{pH}$ of fresh milk was 6.9, while it was 6.7 for homogenized cow milk. Compared with cow milk, the acidification of goat milk was stronger due to heat. Therefore, in the process of milk production, the germicidal heating conditions of two different milk sources should be determined according to their thermal stability.
\end{abstract}

\section{Introduction}

In the process of thermal processing, there are some problems such as protein flocculation and poor solidification, resulting in the decrease of milk stability during storage. The less casein, calcium and phosphate content of goat milk affect its micelle system, so goat milk has low colloidal stability, leading to the more poor thermal stability of goat milk than cow milk[1,2]. So the processing conditions should also be different for the milk from the different sources[3]. At present, domestic goat milk products are mainly sheep milk powder, and a small amount of liquid milk and fermentation products[4]. Therefore, the study on thermal stability of goat milk is of great significance to solve the problem of limited processing of goat milk products. In this paper, the effect of $\mathrm{pH}$ on the thermal stability of goat milk was determined by measuring the heat-induced acidification of goat milk and the thermal coagulation time of fresh milk and homogenized milk under different $\mathrm{pH}$ values. The thermal stability of homogenized milk was analyzed while comparing the thermal stability of goat milk and cattle milk. It aimed to provide reference for optimizing the production process of goat milk and its products and solving the problem of limited processing and application of goat milk.

\section{Materials and methods}

\subsection{Collection of goat milk and cow milk}

The goat milk was collected from Sanxi dairy goat farms in Taian, Shandong, and cow milk from Shandong Xingniu Dairy Co., Ltd. These two farms were well organized and utilizes free stall barn raising and a total mixed rations (TMR) silage diet. Machine milking were carried out according to the milk sample collection process in the farm. Samples were collected in sterile bottles and transported back to the laboratory in cold chain. The milk samples were filtered, preheated $\left(60 \sim 65^{\circ} \mathrm{C} \backslash 15 \mathrm{~s}\right)$, homogenized $\left(60 \sim 65^{\circ} \mathrm{C} \backslash 20 \mathrm{MPa}\right)$ and analyzed.

\subsection{Method}

The thermal stability of milk were determined according to the Fox heat coagulation time method[5]. The $\mathrm{pH}$ was adjusted to $6.1-7.5$ with $10 \%$ acetic acid solution and $1 \mathrm{~mol}$ / L sodium hydroxide solution, respectively to determine the thermal stability of milk samples at different $\mathrm{pH}$ value.

Milk samples were heated and refluxed in a $140{ }^{\circ} \mathrm{C}$ constant temperature oil bath for $180 \mathrm{~min}$, and take samples every $20 \mathrm{~min}$ for determination of $\mathrm{pH}$ and acidity, repeating the sampling three times for each of milk groups. PHS-25 pH meter was used to determine the $\mathrm{pH}$ of the samples. The acidity was expressed in volume of $\mathrm{NaOH}$ $(0.1 \mathrm{~N})$ consumed to neutralize $100 \mathrm{ml}$ of milk.

\subsection{Statistical analysis}

EXCEL 2016, Origin 8.0 and IBM SPSS Statistics 23 software were used for data analysis. The results of the experiment are expressed as means \pm standard deviations (SD).

\footnotetext{
* Corresponding authors e-mail: Cunfang Wang, cunfangwang@163.com and Hua Jiang, 4279833@qq.com
} 


\section{Results and Discussion}

\subsection{Analysis on the thermal stability of goat milk due to $\mathrm{pH}$}

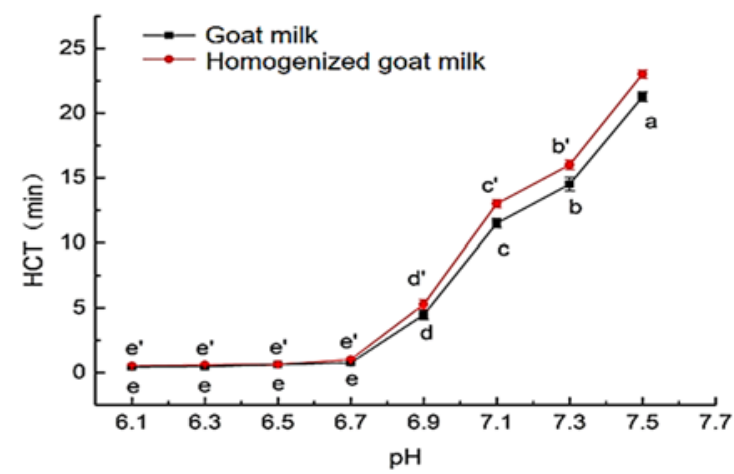

Figure 1. The heat stability of goat milk and homogenized goat milk due to $\mathrm{pH}$

There were two different types of $\mathrm{pH}-\mathrm{HCT}$ curves for milk. HCT change of type A milk was closely related to $\mathrm{pH}$, and had the maximum and minimum thermal stability, which was manifested as bimodal structure in the pH-HCT characteristic curve. The $\mathrm{pH}-\mathrm{HCT}$ characteristic curve of type B milk showed an upward curve, and the thermal stability increased with the increasing of $\mathrm{pH}$ value. It could be seen from Figure 1 that the goat milk belonged to type $\mathrm{B}$ milk. The changes of $\mathrm{pH}$ in the range of 6.7-7.7 had significant effect on the thermal stability of raw milk and homogenized milk $(\mathrm{P}<0.05)$. The change trend of thermosetting time with $\mathrm{pH}$ value for fresh goat milk was the same with homogenized goat milk and the thermosetting time was prolonged with the increasing of $\mathrm{pH}$ value, indicating that the thermal stability was positively correlated $\mathrm{pH}$ value whether fresh or homogenized for goat milk. When the $\mathrm{pH}$ was in the range of 6.1-6.7, no significant increase was observed for the thermal stability of fresh and homogenized goat milk ( $\mathrm{P}>$ $0.05)$.

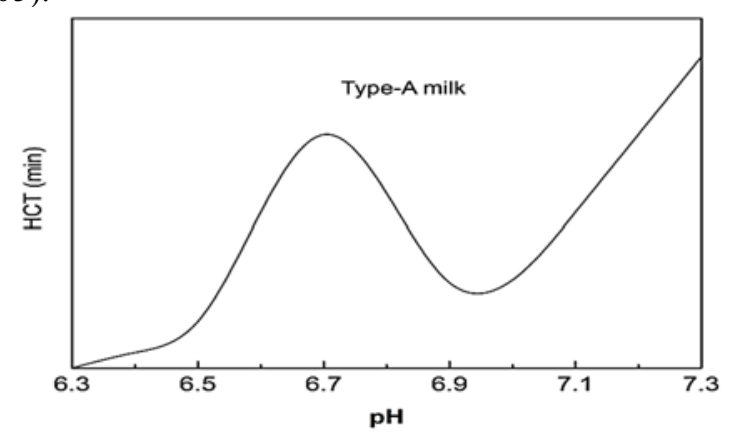

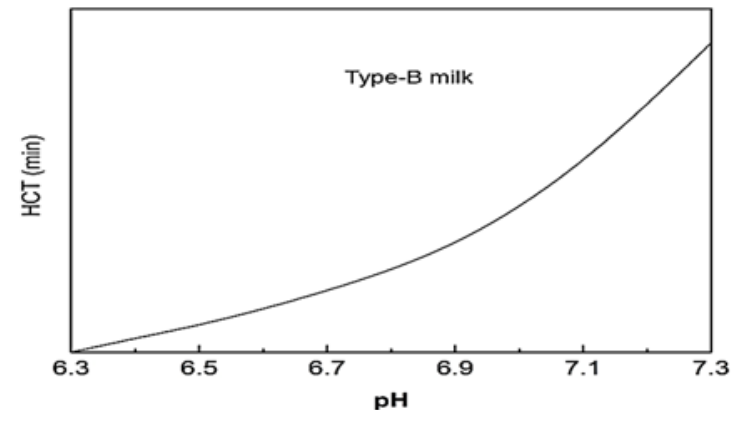

Figure 2. Effect of $\mathrm{pH}$ on the thermosetting time of type A milk and type B milk

The thermal stability of goat milk and homogenized goat milk increased with the increase of $\mathrm{pH}$, indicating that the change of $\mathrm{pH}$ affected the interaction between milk proteins and the balance of salt ions (especially free calcium ions) in solution. The physiological $\mathrm{pH}$ of goat milk was about $6.7 \sim 6.8$, and the milk protein was charged negatively. When heat-treated near low $\mathrm{pH}$, the thermally denatured whey protein polymerized with the $\mathrm{\kappa}-\mathrm{CN}$ on the casein surface via the disulfide bond to form a whey protein/casein polymer. The polymerization occurred mainly on the surface of casein micellar. Therefore, the aggregation of milk was larger and the thermal stability of milk was lower near the low $\mathrm{pH}$ value. With the increase of $\mathrm{pH}$, the negative charge on the surface of milk protein increased, and the resultant force of water and the $\zeta$ potential increased, so milk protein was not easy to agglomerate. The calcium ion activity which had a great influence on the stability of milk protein decreased, so the thermal stability of milk increased. When heat-treated at high $\mathrm{pH}$, the heat-denatured whey protein would bind to $\mathrm{\kappa}$ $\mathrm{CN}$ via a disulfide bond. The $\kappa-\mathrm{CN}$ and its polymers were depolymerized on the surface of casein to form the soluble complex of WP / $\mathrm{\kappa}-\mathrm{CN}$, which mainly existed and dissolved in whey phase[6]. And the complex increased with the increase of $\mathrm{pH}$, so the coagulation of milk was small, and the thermal stability of milk was high[7]. The results of this paper were consistent with those of Zhao et al. [8]

\subsection{Analysis on the thermal stability of cow milk due to $\mathrm{pH}$}

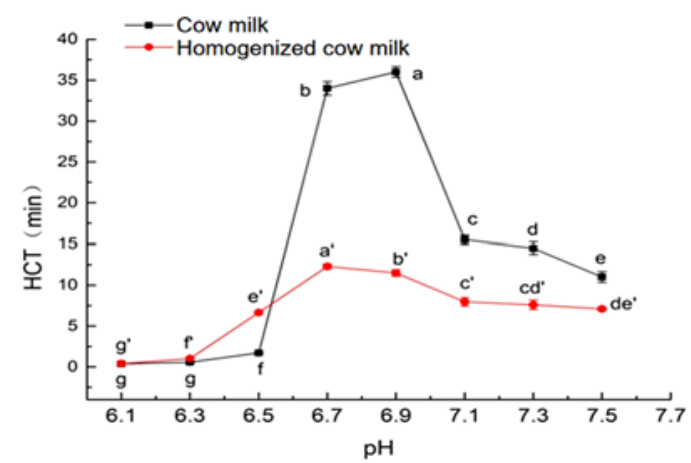

Figure 3. The heat stability of cow milk and homogenized cow milk due to $\mathrm{pH}$ 
According to Figure 3, cow milk was of type A milk. The most stable $\mathrm{pH}$ of cow milk was 6.9 , and it was 6.7 for the homogenized cow milk. There were significant effects of $\mathrm{pH}$ on the thermal stability of both fresh and homogenized cow milk $(\mathrm{P}<0.05)$. At $140^{\circ} \mathrm{C}$ heat treatment temperature, the thermal setting time of both milk and homogenized milk increased first and then decreased with the increase of $\mathrm{pH}$ value. For type A milk, when the $\mathrm{pH}$ value was less than 6.3 , the $\zeta$-potential of the protein and the hydration of micelles were low, and the calcium ion activity was high, resulting in the poor thermal stability of milk. So, flocculation quickly occurred at $140^{\circ} \mathrm{C}$. In the vicinity of stable $\mathrm{pH}$, the $\beta$-Lg $/ \kappa-\mathrm{CN}$ complex, which produced at high temperature, reduced the depolymerization of $\kappa-\mathrm{CN}$ on the micelle surface, and increased the steric hindrance, $\zeta$-potential and hydration, resulting in the stable of milk in the vicinity of the $\mathrm{pH}[9]$. In the alkaline $\mathrm{pH}$, high temperature depolymerized $\kappa-\mathrm{CN}$ on the surface of micelles and existed alone or combined with $\beta$-Lg in whey phase, resulting in an increase of calcium concentration. The casein micelles separated from $\kappa-\mathrm{CN}$ were easy to form precipitation during heating, so the thermal stability of emulsion in alkaline $\mathrm{pH}$ was reduced again [10].

The thermosetting time of homogenized milk at the most stable $\mathrm{pH}$ value was significantly lower than fresh milk $(\mathrm{P}<0.05)$, indicating that homogenization treatment reduced the thermal stability of milk. The reason might be that homogenization caused the fragmentation of milk fat spheres, the particle size of milk fat spheres became smaller, the number of fat spheres increased, and the interfacial area between milk fat and water increased[11]. As a result, more proteins could be adsorbed on the surface of milk fat spheres, which reduced the thermal stability of milk.

\subsection{Heat - induced acidification of cow milk and goat milk}

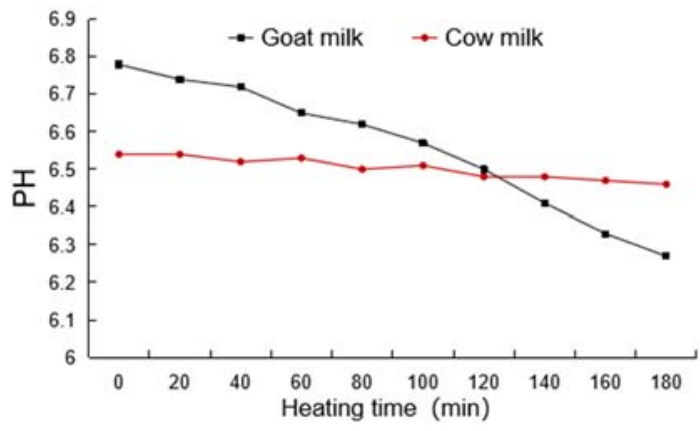

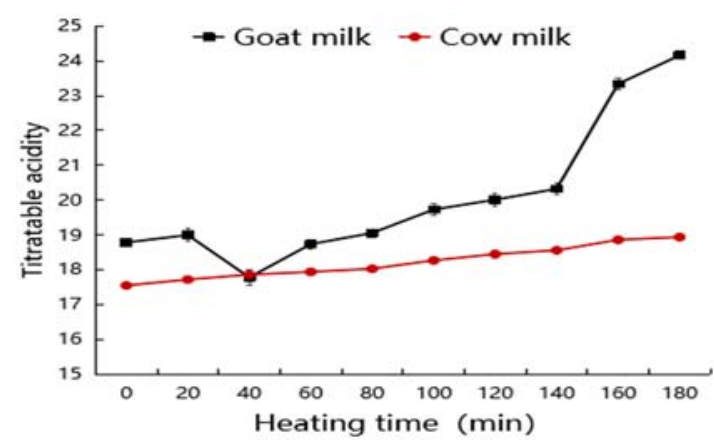

Fig 4. The heat-induced acidification of goat milk and cow milk

As figure 4 showed, during the heat treatment at $140^{\circ} \mathrm{C}$, the change of heat treatment time had a significant influence on the $\mathrm{pH}$ value of cow milk $(\mathrm{P}<0.05)$. Heatinduced acidification would occur in the heating process, resulting in a decrease in $\mathrm{pH}$, and neutralizing a part of the negative charge on the surface of milk protein. And that would lead to a decrease in the electrostatic repulsion between proteins and make it easier for milk protein to aggregate in the heating process[12]. Heat-induced acidification is one of the main factors causing milk heat instability.

\section{Conclusion}

Goat milk was of Type B milk, the thermal stability of fresh milk and homogenized milk was positively correlated with $\mathrm{pH}$ value. While cow milk was of A type milk, the most stable $\mathrm{pH}$ of fresh milk was 6.9 , and it was 6.7 for homogenized cow milk. There were significant differences for the thermal stability of goat milk compared with cow milk, and it was dependent on the change of $\mathrm{pH}$ value significantly, but the dependent degree was quite different for the milk from different sources. In the process of heat-induced acidification, the $\mathrm{pH}$ of goat milk gradually decreased, and the titratable acidity increased with the extension of heat treatment time. The influences of homogenization on the thermal stability of two different milk sources were also different, which might be related to the different characteristics of milk from different sources, such as Type B milk or type A milk. And the root cause needs further to be studied.

\section{Acknowledgments}

This work was supported by the Key Research and Development Program of Shandong province (2019YYSP025), Shandong Major Agricultural Technology Innovation Project (SD2019ZZ006) and National College Student Innovation and Entrepreneurship Training Program (201910431002).

\section{References}

1. Chen, D., et al., Comparative proteomics of goat milk 
during heated processing. Food Chemistry, 2019. 275: p. 504-514.

2. Cunfang Wang, Y.Z., Jianmin Wang, Comparative study on the heat stability of goat milk and cow milk $[\mathrm{J}]$. Indian Journal of Animal Research,2016,50(4). Indian Journal of Animal Research, 2016: p. 50(4).

3. Qin, Y., et al., Comparative Study on the Microstructure and Functional Properties of Casein in Goat Milk Processed by Different Methods. international journal of food science and technology, 2020 .

4. Langer, P., Goat milk products: types of products, manufacturing technology, chemical composition, and marketing. Mammalian Biology, 2008. 73(5): p. 412.

5. Wijayanti, H.B., N. Bansal, and H.C. Deeth, Stability of Whey Proteins during Thermal Processing: A Review. comprehensive reviews in food science and food safety, 2014. 13(6): p. 1235-1251.

6. Fox, P.F., et al., Heat-Induced Changes in Milk. international dairy federation special issue, 2015: p. 345-375.

7. Singh, H., Heat stability of milk. international journal of dairy technology, 2004. 57: p. 111-119.

8. Zhao, L., et al., Effects of heat treatment and stabilizing salts supplementation on the physicochemical properties, protein structure and salts balance of goat milk. lwt food science and technology, 2020. 132.

9. Dumpler, J., Heat Stability of Concentrated Milk Systems. 2018.

10. O'Connell, J.E. and P.F. Fox, Heat-Induced Coagulation of Milk. 2003. p. 879-945.

11. Chen, D., et al., Proteomics and microstructure profiling of goat milk protein after homogenization. journal of dairy science, 2019. 102(5): p. 3839-3850.

12. Li, Q., et al., Effect of $\mathrm{pH}$ on heat stability of yak milk protein \%J International Dairy Journal. 2014. 35(1). 